\section{B A Institute of \\ yk Business Administration \\ 六下 \\ Karachi \\ Leadership and Ideas for Tomorrow}

Business Review

Volume 2 Issue 1 January - June 2007

$1-1-2007$

\title{
Diversification in banking sector with special reference to finance
}

Yaseen Ahmed Meenai

Institute of Business Administration, Karachi, Pakistan

Follow this and additional works at: https://ir.iba.edu.pk/businessreview

Part of the Finance and Financial Management Commons

(c) (1)

This work is licensed under a Creative Commons Attribution 4.0 International License.

\section{Recommended Citation}

Meenai, Y. A. (2007). Diversification in banking sector with special reference to finance. Business Review, 2(1), 189-199. Retrieved from https://doi.org/10.54784/1990-6587.1122

This article is brought to you by iRepository for open access under the Creative Commons Attribution 4.0 License and is available at https://ir.iba.edu.pk/businessreview/vol2/iss1/15. For more information, please contact irepository@iba.edu.pk. 


\title{
DISCUSSION
}

\section{Diversification in Banking Sector with Special Reference to Finance}

\author{
Yaseen Ahmed Meenai \\ Institute of Business Administration, Karachi
}

\section{SUMMARY}

Diversification in Banking Sector is relatively a new phenomenon. The aim of this article was to analyze the boom in banking sector with special reference to CONSUMER FINANCING. For this purpose, financial products - Credit cards, Home financing and Car financing - of different banks were selected and their policies were analyzed.

My goal was to find the reasons behind the diversification in Banking Sector particularly in Consumer financing over the last 10 years. For this, I collect the data from different banks to analyze the factors involving in it.

After analyzing the various aspects of financing strategy in banks, I concluded that the major reason behind the boom in consumer financing is INFLATION. Purchasing power of the people has greatly reduced for the past ten years. Due to this reason people were attracted towards the policies, which different banks are offering in different products like home, cars and home appliances, with minimum down payment and minimum markup.

Another reason behind the boom is $9 / 11$ incident. After the incident the liquidity form of money in Pakistan was raised with a great extent, because Pakistanis living in European countries and America projected their future in danger. So they transfer their earnings to their homeland. This is the reason, which raised the liquidation of money in the economy. In order to overcome this problem, State Bank ordered the commercial banks too lower their interest rates so that people will invest their earnings in Banks.

\subsection{BANKING \& FINANCIAL SECTOR IN PAKISTAN}

D akistan is one of the key emerging markets of South Asia with a total population of over 140 million people. Pakistan's GDP is expected to grow at over 5\% during the year 2004-05. Macroeconomic stability and financial sector reform are targeted to have a positive, substantial impact on real economy.

The banking sector in Pakistan consists of Commercial Banks and Specialized Banking Institutions. During the 8 months of financial year 2004 as per SBP Quarterly report there has been robust growth in deposit mobilization and credit off take with a rise of PKR 150 billion in net credit to the private sector (Aazim 2004). 


\subsection{CHANGES IN SELECTED BANKING SECTOR INDICATORS}

\begin{tabular}{lrrr} 
& \multicolumn{3}{c}{ Billion Rupees } \\
\hline & FY 01 & FY 02 & FY 03 \\
\hline & 112.2 & 173.5 & 275.1 \\
Deposit Mobilization & 105.9 & 199.3 & 387.3 \\
Gross Disbursements & 66.9 & 41.7 & 133.2 \\
Net Credit & 54.3 & 32.3 & 167.7 \\
Credit to Private Sector & 18.8 & 14.0 & -7.0 \\
Stock of NPLs & 103.0 & -185.0 & -454.0 \\
WA lending rates (basis points) & -89.0 & -83.0 & -227.0 \\
WA deposit rates (basis points) & \multicolumn{4}{c}{}
\end{tabular}

The following correlation matrix showing the strong + ve relationship b/w financial years 2002 and 2003 with respect to all the categories shown in the table 1.2. So we can say that banking seems to be uniform in all categories in terms of liquidity form and its approx. $97.37 \%$ associated.

\section{Correlation Matrix}

\begin{tabular}{lrrr}
\hline & \multicolumn{1}{c}{ FY 01 } & FY 02 & FY 03 \\
\hline FY 01 & 1 & & \\
FY 02 & 0.408797 & 1 & \\
FY 03 & 0.387362 & $\mathbf{0 . 9 7 3 7}$ & 1 \\
\hline
\end{tabular}

The performance of the Pakistani banking sector has improved considerably in the years 2002 and 2003 on account of the following:

- The performance of nationalized banks has significantly improved as the restructuring process initiated in these banks since the year 1997 has begun to show positive results.

- Banks, especially the nationalized banks have taken steps, to reduce their administrative expenses.

- The tax rates have reduced from $58 \%$ in 2001 to $50 \%$ in 2002 to $44 \%$ in 2003 to $41 \%$ in 2004 and will decline to $38 \%$ in 2005 and reach $35 \%$ for 2006 onwards.

- The State Bank of Pakistan/ Ministry of Finance has also introduced several reforms in the banking sector.

The key trends in the banking sector are as follows:

- Increased Merger \& Acquisition activity in the banking sector with local private banks having made several domestic acquisitions. 
- Large expansion of branch network and deposits by private and some foreign banks.

- Rationalizations of branches by nationalized banks.

- Increased focus towards consumer finance.

- Increased focus on attracting local rupee deposits.

- Increased emphasis towards automation and customer service.

- Reduction in the increase in non performing loans as a result of better governance of banks and greater accountability process initiated by the government.

Significant increase in inward remittance business as a result of governmental clamp down on unofficial remittance channels following September 11.

\subsection{CONSUMER FINANCING}

Apart from the specific regulations given under each mode of financing separately, general requirements laid down here should also be followed by the banks / DFIs while undertaking consumer financing. It may be noted that these are the minimum requirements and should not in any way be construed be restrict the role of the management of the banks / DFIs to further strengthen the risk management processes through establishing comprehensive credit risk management systems appropriate to their type, scope, sophistication and scale of operations. The Board of Directors of the bank / DFIs are required to establish policies, procedures and practice to define risks, stipulate responsibilities, specify security requirements, design internal controls and then ensure strict compliance with them.

The banks / DFIs must clearly disclose, all the important terms, conditions, fees, charges and penalties, which interalia include Annualized Percentage Rate. Pre-payment penalties and the conditions under which they apply. For ease of reference and guidance of their customer, banks / DFIs are encouraged to publish brochures regarding frequently asked questions.

Recent weeks and months have witnessed generous advertisements by banks, both in dimensions and frequency, on consumer financing, i.e. for purchase, on installments, of durable consumer goods such as automobiles, household electronic goods, housing units, etc. dotting the national print media, heralding emergence of a new sector in commercial banking and financial-services sector of the economy.

The savings of small earners or of middle-class, anxious to save for rainy days, constitute the bulk of bank deposits. Banking has been one of the instruments of the exploitative structure that goes by the name of politico-economic order in this country where politics has always dictated economics; squeezing the shrimps to feed and fatten the sharks. Initiation and promotion of consumer financing is a very welcome 
development, as a potential source of contribution to socio-economic stability and towards growth of middle class envisaged to be the backbone of democracy.

As a corollary to the absence of active and effective movement to protect consumers' interests, consumers' needs for loans by the money market have merited scant attention of the banking system in Pakistan over the past decades. As such consumer credits launch by the banking and financial-services sector can be billed as a positive measure macro-economically. Advanced and progressive economies striving to attain socioeconomic equilibrium are known for offering opportunities, both for producers and consumers, resorting to the lending system to meet their requirements for cash on loan. One of the reasons for socio-economic stability and the promotion of democracy in these countries can be traced to this arrangement.

Given the reliable flow of income, one has the possibility to enjoy the benefits of larger range of goods and facilities financed through credit than going in for their oneshot out-of-pocket purchase. In rich economies, where this arrangement is a common practice, it has also greatly contributed to their economic dynamic. To consume something first needs to be produced; consumption by one, is the production by other: this is how modern productive system operates.

The situation has resulted in lot of liquidity with banks keen to do their job of allocating capital in the economy while making a healthy return for themselves. This ushered in a phase where consumer financing offers a growth- promising segment in financial services, "the single most powerful theme in Asian financial services" as termed by SSB part of Citigroup.

Governments are equally positive since this concerns the real economy. Whether it is the construction of houses being financed by mortgages, purchase of long-life consumer goods or revolving credit-card loans and unsecured loans, they all contribute to create demand promote production and generate employment.

The recent interest by banking and financial-services sector in consumer financing in Pakistan is a healthy sign to log on to the trends and directions emerging in Asia. While the performance of the NAB over the past years leaves a lot to be desired, it has certainly sent a shock wave for potential credit sharks that acquisition of heavy loans without intention of paying back, may prove highly unpleasant and torturing. This pressure must not be relaxed.

This would contribute to the liquidity of banking sector to finance households' loan requirements. The State Bank has also a positive approach in this regard. What is required is to set parameters for a total environment conducive to successful and effective consumer financing. The banks are required to set affordable mark-ups, the manufacturers of durable household goods to avoid supply of sub-standard products, the vendor/trader should not over-shoot in quest of profits and the households/consumers would have to keep up credibility while enjoying the benefits of consumer finance banking. 
The concerned state institutions would have to ensure a viable and equitable watchdog function so that all stakeholders in the venture share the benefits. A well conceived, implemented and monitored and macro-economically-organized scheme of consumer financing can be a potent contributor to lift up the economy and generate employment.

It was only 2001, when banking sector faced a liquidity glut and declining yields in their traditional business lines that banks began to focus more strongly on the potential offered by this relatively untapped and higher yielding market segment. As a consequence, Pakistan witnessed remarkable growth in consumer finance over the last two years. Specifically, banks' exposure toward consumer financing increased to Rs. 45.1 billion by end-June 2003, up a spectacular 639 percent as compared to the mere Rs. 6.1 billion by end-June 2000 .

A break-up of the consumer financing by category shows that, by end-June FY03, personal loans (others) accounted for more than 40 percent of total credit, followed by the auto finance while other products are still in their infancy; these too appear to be growing strongly.

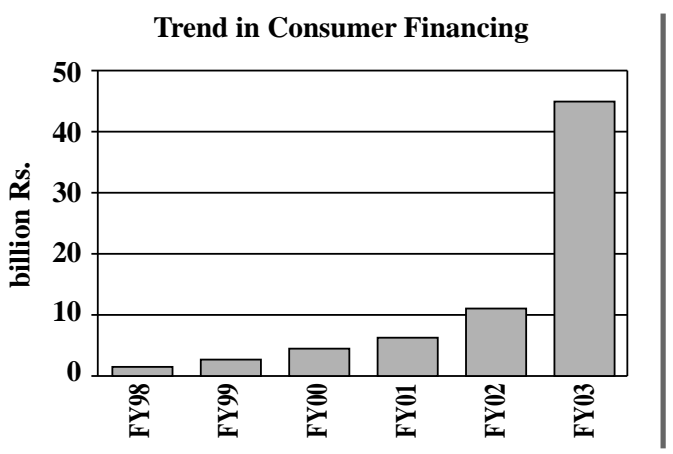

\section{FY03 Composition of Consumer}

Financing

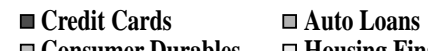
$\square$ Consumer Durables $\quad \square$ Housing Finance $\square$ Others

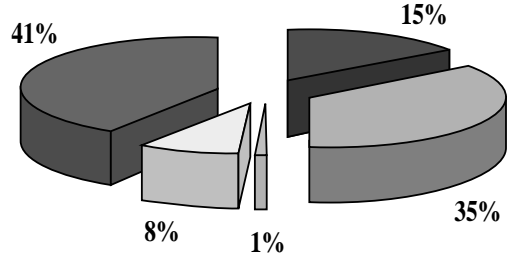

Financing through credit cards is another well established e-banking activity in Pakistan, and it has witnessed remarkable growth since CY00. The number of credit cardholders and volume of transaction have both significantly increased during last three years (see Fig 1.3 Symmetric Plot of Correspondence Analysis*) showing the initiative given by CITIBANK and STANDARD CHARTERED in FY 2000-02, after this period, some other banks also started their credit cards. This sharp rise was facilitated by improving ebanking infrastructure and rising banks' interest in the area of consumer financing. While the total number of POs terminals has increased to 8616 by the end of March 2003, net credit expansion to consumer financing surged to Rs. 59.3 billion by end-June 2003 . 
Fig. 1.3

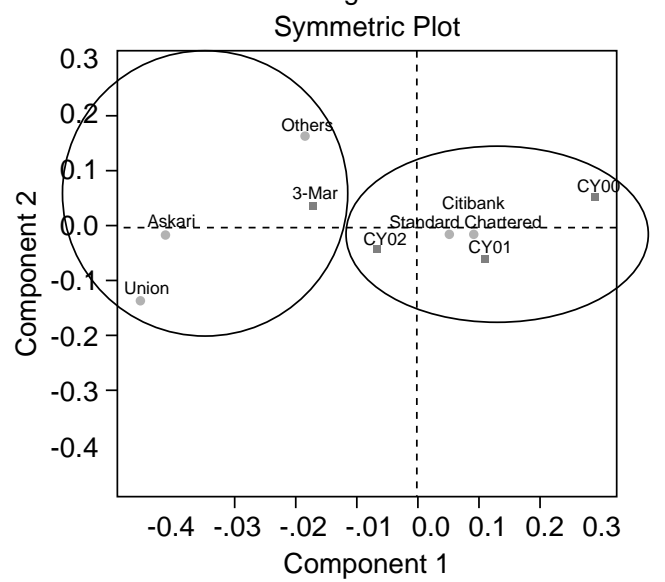

* $\quad$ Simple Correspondence Analysis helps you explore relationships in a twoway contingency table, that is, a table of frequencies based on two categorical variables. You can also use simple correspondence analysis to analyze three-way and four-way contingency tables.

Table 4: Financing to SMEs and Consumer Sector by the Banking System

Domestic Operations

\begin{tabular}{lrrr} 
& \multicolumn{3}{c}{ Billion Rupees } \\
\hline & Dec-02 & Dec-03 & Jun-04 \\
SME Financing & & & \\
Consumer Financing & 170.0 & 215.0 & 250.6 \\
$\quad$ Credit Cards & 22.6 & 65.5 & 102.6 \\
Auto Loans & 6.1 & 8.9 & 11.2 \\
Housing Loans & 8.3 & 22.2 & 33.1 \\
Other (Durables and personal loans) & 6.3 & 30.3 & 50.3 \\
\hline
\end{tabular}

Source: Banking Supervision Department, SBP

If we analyze above figures using the Profile Analysis*, then we can observe the raise in each category of Financing including the credit card holders but the increment seems to be with a lower ratio in SME financing sector while it is rapid in consumer financing, home loan \& auto loan sectors. Yearwise profiles are given below:
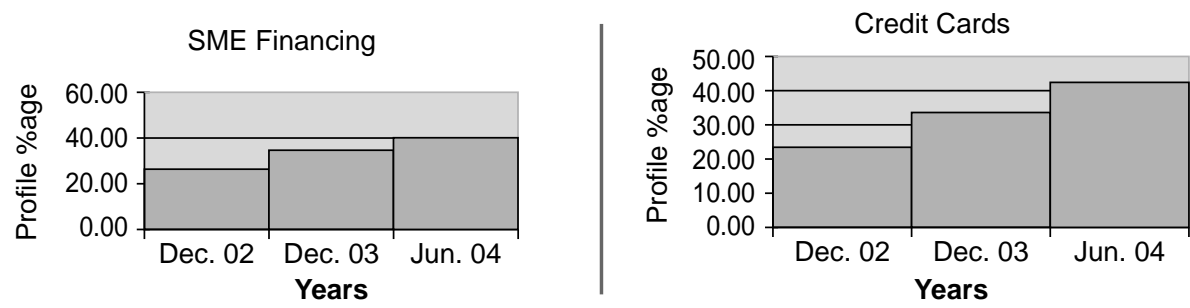


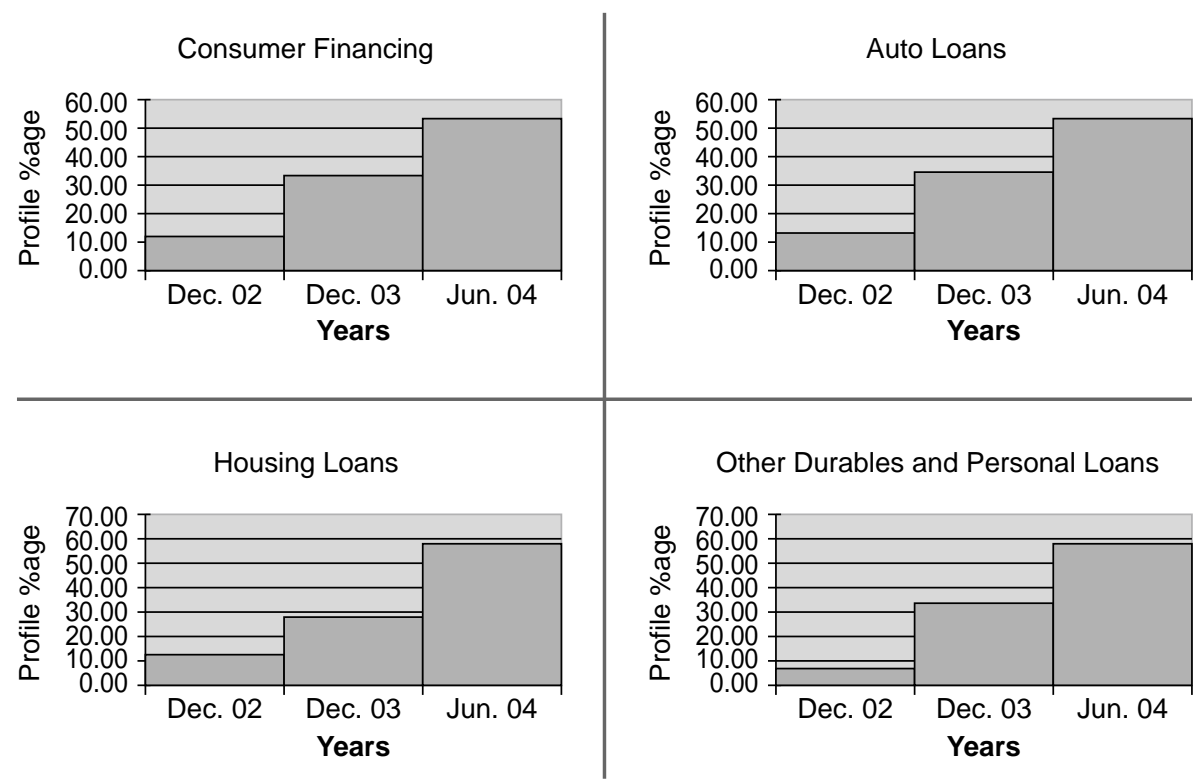

* Profiles are proportions that are calculated from the counts, nij, in the original data table. Specifically, the profile for row $i$ is (nil / ni., ..., nic / ni.); The average row profile is calculated from the column totals.

Although a few banks had been extending auto loans since the mid-1990s, the business segment remained largely in the domain of leasing companies until recently. Over the last two years many banks have launched car financing schemes and marketing aggressively. Combined net credit of all banks for auto financing reached at Rs. 15.8 billion by end FY03. This is substantially higher as compared to the aggregate total of only Rs. 3.5 billion in FY01 (similar pattern can be observed by the profile of autoloan). In sharp contrast to the credit cards and auto loans market where banks were free to undertake these business activities, housing finance by banks was barred until the May 5, 1998, prior to the issuance of a National Housing Policy. Policy guidelines first issued in July 2001 were further liberalized in June 2003 keeping requirements of stakeholders and risk managing capacity of the banks in mind. Another very important development was the Financial Institutions (Recovery of Finance) Ordinance 2001, which empower banks to recovery collateral without recourse to potentially lengthy and expensive court proceedings.

The main characteristics of the credit policy for housing finance are summarized in the above table $\&$ in profile. As a result of these policy initiatives and increasing banks' interest in housing finance, net credit to this sector reached at Rs. 4.1 by end-FY03. 


\subsubsection{Interest Rate}

The SBP started reducing the discount rate gradually from 14 percent in June 2001 to 7.5 percent in November 2002. Since then, the SBP has kept the discount rate stagnant at 7.5 percent, which reflects the commitment of SBP towards keeping a low interest rate environment.

However, the 6-month T-Bills rate, which is also, a benchmark rate, started edging up after reaching at its lowest in August 2003. As the benchmark T-Bills rate is more sensitive to money market conditions and other economic indicators, the T-Bills rate started inching up in the later half of September 2003 on account of increase in foreign interest rates, increase in domestic inflation particularly in the non-food component, depreciation of Rupee vis-à-vis US Dollar and higher demand for bank credit due to seasonal factors. The rates on $\mathrm{T}$-Bills with different maturities also increased during the period. Similarly, the export refinance rate, which was linked with the 6-months T-Bills rate, also increased from 1.5 percent as in June 2003 to 2 percent as in June 2004 (SBP-APR 2003-04).

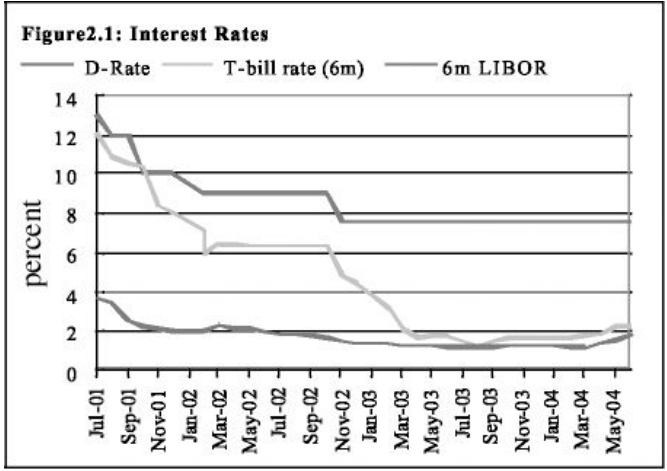

\subsection{E-BANKING}

"In the 21st Century there will be a lot of banking but there will be no banks." (Bill Gates)

In recent years, Automated Teller Machines (ATM), Tele Banking, Internet Banking, Credit and Debit Cards, etc. have emerged as effective delivery channels for traditional banking products in Pakistan.

Foreign banks took the lead by re-introducing credit cards to the Pakistani mass market in mid-1990s. This was followed by the domestic banks, which introduced ATM facility in late 1990s. However, this delayed entry in e-banking may be largely explainable by regulatory hurdles, higher start-up costs, on-going banking sector reforms, and lack of technical skills. 
At present, a number of commercial banks have set up their own standalone ATM networks, issuing credit and debit cards, offering round the clock phone banking, and maintain comprehensive websites providing detailed information on their conventional and e-banking products. Furthermore, all banks have joined one of the two operating ATM Switch Networks and these two switches are in process of linkage with each other. Have linked these two switches, customers will have access to over four hundreds ATMs throughout Pakistan. (39) However, other e-banking activities are yet to establish.

In Pakistan, the ATMs generally allow cash withdrawals, balance information, PIN change, and to print mini-statement. A few banks also provide fund transfers, checkbook request, and utility bill payment facilities through their ATM networks. A quick glance at Table 1.4 shows that the number of ATMs, cardholders and cash withdrawals have sharply increased since CY00. As a result, the value of ATM transactions has also recorded strong growth over the same period.

Table 1.4: Position of ATM

\begin{tabular}{lrrrr}
\hline & CY00 & CY01 & CY02 & Jun-03 \\
\hline No. of on-line branches & & & & \\
No. of ATMs & 322 & 450 & 777 & 994 \\
No. of card holders (000) & 206 & 259 & 399 & 445 \\
No. of transactions (000) & 240 & 415 & 736 & 838 \\
Value of transactions (million) & 3624 & 5923 & 9319 & 6450 \\
Value per transaction (Rupees) & 12507 & 22108 & 37786 & 28052 \\
\hline
\end{tabular}

The profile analysis also signifies the e-banking boost during the above mentioned period of time, the same time-period is taken because the changing occurs significantly during these years, now we have to take a look on the profiles to identify the pattern during 4 years:

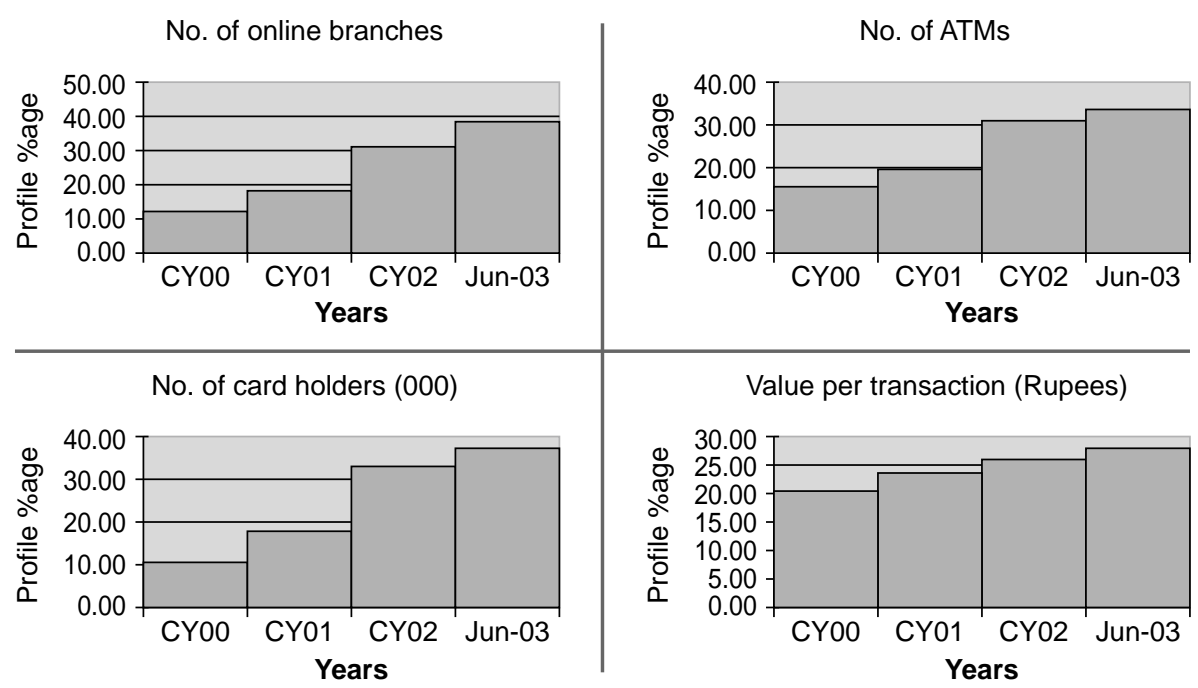


The pattern seems to be rising during years from 2000 to 2003. The number of ATMs, which was close to 207 at the end of 2000 , has increased to 676 ATMs as of June 2004. Similarly, online branches of commercial banks have grown over 6 times to 2,181 during the same period. The volume and value of business transactions through the ATMs have also witnessed a steady rise. The number of credit card holders has multiplied three-fold from 200,000 to over 600,000 cardholders during the last four years. Also, the average monthly volume of transactions has more than doubled in the same period, see the following figures (APR-SBP-2003-04).
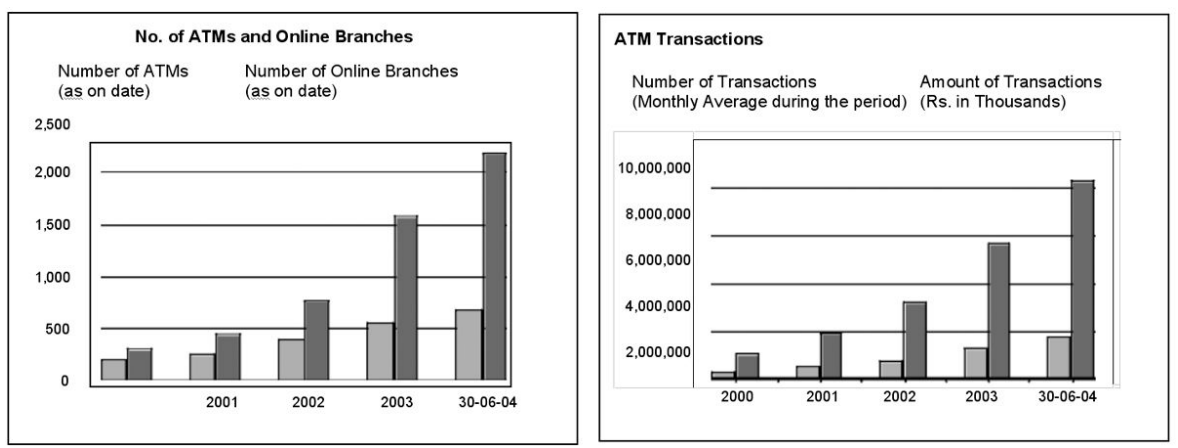

\section{CONCLUSIONS}

Many domestic banks have improved their working standards. For instance, the internetbased services are being offered, ATM machines are being installed, the number of Debit and Credit Cards is on the increase at an unprecedented rate, and last but not least, consumer financing has taken a new shape and dimension. The increased borrowing by the private sector has influenced the economy favorably by generating economic activity and in the process the profitability of the banks has also improved. Around 2 million households are direct beneficiaries of the latest initiatives of the banks such as Microfinance, Consumer loans and diversified Mortgages schemes.

\section{RECENT INITIATIVE}

The Islamic Banking has been introduced in parallel with the conventional banking and the SBP has setup a full-fledged Islamic Banking Department. The Shariah Board has also been established to promote Islamic modes of banking in the country. The Islamic banking is attracting a large majority of customers who prefer interest free banking on religious grounds.

\section{REFERENCES}

State Bank of Pakistan, Annual Performance Review, 2003-04, A State Bank Publication, pg. 26-33. 
CBR Quarterly Review, April -June 2006, Vol. 5, No. 4, Government of Pakistan, Constitution Avenue, Islamabad-Pakistan, pg. 31-32.

Hussain, Ishrat, 2005, Banking Sector Reforms, Blue Chip Magazine, Islamabad.

Meenai, Uddin, 2003, A Proposed MINITAB Macro for Enhancing the Correspondence Analysis, Proc. 113-118.

Greenacre, M.J. 1983, Theory and Applications of Correspondence Analysis, Academic Press, London

Williams, E.J. 1952, Use of scores for the analysis of association in contingency tables, Biometrika, 39, 274-298.

Leading from good to great does not mean coming up with the answers and then motivating everyone to follow your messianic vision. It means having the humility to grasp the fact that you do not yet understand enough to have the answers and then to ask the questions that will lead to the best possible insights.

Jim Collins 